NBER WORKING PAPER SERIES

\title{
HAS THE U.S. WAGE PHILLIPS CURVE FLATTENED? A SEMI-STRUCTURAL EXPLORATION
}

\author{
Jordi Galí \\ Luca Gambetti \\ Working Paper 25476 \\ http://www.nber.org/papers/w25476
NATIONAL BUREAU OF ECONOMIC RESEARCH
1050 Massachusetts Avenue
Cambridge, MA 02138
January 2019

Prepared for the XXII Conference of the Central Bank of Chile, Santiago, October 25-26. We are grateful for comments to Fernanda Nechio, Régis Barnichon, Geert Mesters as well as participants at the CREi Faculty lunch and the Central Bank of Chile conference. The views expressed herein are those of the authors and do not necessarily reflect the views of the National Bureau of Economic Research.

NBER working papers are circulated for discussion and comment purposes. They have not been peer-reviewed or been subject to the review by the NBER Board of Directors that accompanies official NBER publications.

(C) 2019 by Jordi Galí and Luca Gambetti. All rights reserved. Short sections of text, not to exceed two paragraphs, may be quoted without explicit permission provided that full credit, including () notice, is given to the source. 
Has the U.S. Wage Phillips Curve Flattened? A Semi-Structural Exploration

Jordi Galí and Luca Gambetti

NBER Working Paper No. 25476

January 2019

JEL No. E24,E31

\begin{abstract}
Unconditional reduced form estimates of a conventional wage Phillips curve for the U.S. economy point to a decline in its slope coefficient in recent years, as well as a shrinking role of lagged price inflation in the determination of wage inflation. We provide estimates of a conditional wage Phillips curve, based on a structural decomposition of wage, price and unemployment data generated by a VAR with time varying coefficients, identified by a combination of long-run and sign restrictions. Our estimates show that the key qualitative findings from the unconditional reduced form regressions also emerge in the conditional evidence, suggesting that they are not entirely driven by endogeneity problems or possible changes over time in the importance of of wage markup shocks. The conditional evidence, however, suggests that actual changes in the slope of the wage Phillips curve may not have been as large as implied by the unconditional estimates.
\end{abstract}

\author{
Jordi Galí \\ Centre de Recerca en Economia Internacional (CREI) \\ Ramon Trias Fargas 25 \\ 08005 Barcelona \\ SPAIN \\ and NBER \\ jgali@crei.cat \\ Luca Gambetti \\ Collegio Carlo Alberto \\ Università di Torino \\ luca.gambetti@uab.cat
}




\section{Introduction}

The deep and prolonged recession triggered by the global financial crisis of 2007-2009 led to a large increase in the unemployment rate in most advanced economies. Ten years later, at the time of writing this paper, the recession has long ended, and the subsequent recoveries have brought the unemployment rate to levels close to -and in some cases even below- those at the peak of the previous expansion. In the U.S. the unemployment rate increased from 4.4. percent in May 2007 to 10 percent in November 2009. Since that peak was attained, the unemployment rate has decreased -albeit at a slower pace than in earlier recoveries- down to its current level below 4 percent. Both movements represent, respectively, the largest increase and the largest decrease in the unemployment rate experienced by the US economy during the postwar period. Despite those wide and persistent fluctuations in unemployment, inflation has remained surprisingly stable during the same period, as illustrated in Figure 1. The previous phenomenon, often referred to in the literature as the "twin puzzle," appears to be robust to the measure of inflation and economic slack used, ${ }^{1}$ and has also been observed in other advanced economies. ${ }^{2}$

Not surprisingly, central banks around the world have sounded the alarm in the face of that development, and with good reason. ${ }^{3}$ For one, a flattening of the Phillips curve implies a larger sacrifice ratio and the need for more extreme policy measures in order to eliminate deviations of inflation from target. Furthermore, an outright decoupling of inflation from indicators of economic slack would call into question the inflation targeting framework widely adopted by central banks over the past decades, since that framework hinges critically on the existence of a positive relation between inflation and the level of economic activity, given that it is only through its ability to influence the latter through an appropriate setting of the interest rate and other policy instruments that central banks can aim at controlling inflation.

\footnotetext{
${ }^{1}$ See, e.g. Stock and Watson (2018)

${ }^{2}$ See, e.g., Ciccarelli and Osbat (2017) for euro area evidence.

${ }^{3}$ See, e.g. Constancio (2017).
} 
In the present paper we revisit a key link of the relation between prices and economic activity, namely, the relation between wage inflation and unemployment. That empirical relation, which was the focus of Phillips' (1958) original work, is widely perceived to be at the heart of the "twin puzzle." In particular, the failure of wage inflation to respond sufficiently to the tightening of the labor market in recent years is generally viewed as one of the main factors behind the extremely accommodating monetary policies at central banks like the Federal Reserve or the ECB. Figure 2 shows a scatterplot of wage inflation and the unemployment rate to illustrate that phenomenon. We use quarterly data for the period 1964Q1-2017Q4. ${ }^{4}$ As discussed in Galí (2011a), the absence of a clear inverse relation between the two variables over the full sample period can be attributed to the large changes in mean inflation experienced by the US economy in the '70s ("the Great Inflation") and early '80s (the Volcker disinflation). When we restrict ourselves to the '60s and the Great Moderation period, a clear negative relation between the two variables becomes noticeable. Interestingly, that relation can be seen to become nearly flat in the years of the financial crisis and the subsequent recovery, in a way consistent with the "twin puzzle" hypothesis for price inflation.

In the present paper we seek to accomplish two tasks. First, we document changes in the U.S. wage Phillips curve, using simple reduced form regressions. Secondly, and after discussing the limitations of such a reduced form approach, we report estimates of a conditional wage Phillips curve, based on a structural decomposition of wage, price and unemployment data generated by a VAR with time-varying coefficients and identified by a combination of long-run and sign restrictions.

Our main findings can be summarized as follows. First, our reduced form estimates point to a substantial decline in the estimated coefficients on both lagged inflation and unemployment in the U.S. wage Phillips curve. Secondly, our estimates of conditional wage Phillips curves display similar qualitative re-

\footnotetext{
${ }^{4}$ The wage inflation measure is the (centered) year-on-year change in the (log) average hourly earnings of production and nonsupervisory workers in the private sector, from the Establishment Survey.
} 
sults, suggesting that the reduced evidence is not driven by endogeneity problems or possible changes in the relative importance of wage markup shocks. The conditional evidence, however, suggests that actual changes in the slope of the wage Phillips curve may not have been as large as implied by the unconditional estimates. Finally, we show that the reduced sensitivity of wage inflation to unemployment is also reflected in the estimated changes in a dynamic multiplier statistic relating the time-varying joint responses of wage inflation and unemployment to both demand and monetary policy shocks.

The paper is organized as follows. Section 2 describes the reduced form estimates of a wage Phillips curve and discusses some of its limitations. Section 3 presents our structural VAR model and describes the "semi-structural" evidence based on it. Section 4 concludes.

\section{Wage Inflation and Unemployment: Reduced Form Evidence}

In the present section we provide some reduced form evidence on the changing relation between wage inflation and the unemployment rate in the US economy. The starting point of our empirical analysis is the estimation of a baseline wage inflation Phillips curve given by:

$$
\pi_{t}^{w}=\alpha+\gamma \bar{\pi}_{t-1}^{p}-\varphi u_{t}+\varepsilon_{t}
$$

where $\pi_{t}^{w} \equiv 400\left(w_{t}-w_{t-1}\right)$ is (annualized) quarterly wage inflation (with $w_{t}$ denoting the log nominal wage), $\bar{\pi}_{t}^{p}$ is a measure of price inflation (also annualized), and $u_{t}$ is the unemployment rate. A specification similar to (1) has often been proposed and used in empirical applications. ${ }^{5}$

Table 1A reports the OLS estimates of $\gamma$ and $\varphi$ in (1) for different sample periods, using our baseline specification. We use average hourly earnings of production and nonsupervisory workers in the private sector from the Establishment Survey to construct our wage inflation measure. Our baseline price

\footnotetext{
${ }^{5}$ See e.g. Blanchard and Katz (1999)
} 
inflation measure is the (annualized) quarterly rate of change in the GDP deflator. The civilian unemployment rate is our measure of unemployment. We take 2017Q2, which corresponds to the trough in the unemployment rate, to be the cutoff date splitting the two sample periods.

Several observations stand out. First, for the sample period before the financial crisis, the coefficients on both lagged inflation and unemployment are highly significant and with the expected sign. In particular, the estimated slope coefficient suggests that an increase of 1 percentage point in the unemployment rate is associated with a reduction of (annualized) wage inflation of about 30 basis points, given price inflation.

We uncover substantial changes within the pre-crisis sample period, however. Thus, in the 1986Q1-2007Q2 subsample (roughly corresponding to the Great Moderation) the estimated inflation coefficient becomes much smaller (though still significant), while the negative effect of unemployment on wage inflation is estimated to be about twice as large (and significantly different from the pre-86 period, as reflected in the $p$-value reported).

Our estimates for the period of crisis and the subsequent recovery, shown in the bottom panel of the table, point to a large decline in the sensitivity of wage inflation to the unemployment rate, though the coefficient on the latter still remains significant. While the test of equality of that coefficient between the full pre-crisis and the post-crisis samples can only reject that hypothesis at the 10 percent level (see p-value 1), the equality with the "late" pre-crisis period is rejected with very low p-values (see p-value 2 ). In addition, it is worth noting that the estimated coefficient on lagged inflation becomes insignificant in the more recent subsample period, suggesting a further decline in the importance of price indexation in wage setting over the past decade. ${ }^{6}$

Figures 3A and 3B show the time-varying estimates of $\varphi$ and $\gamma$, respectively, based on a rolling OLS regression with a 32-observation window. The estimates illustrate, in a flexible way, the evidence reported earlier, namely, the consecutive

\footnotetext{
${ }^{6}$ The finding of a reduced importance of lagged inflation since the $1980 \mathrm{~s}$ is consistent with Blanchard's (2016) estimates of price inflation Phillips curves.
} 
steepening (during the Great Moderation) and flattening (during the financial crisis and its aftermath) of the wage Phillips curve in the US, as well as the seeming irrelevance of lagged price inflation since the mid-1980s

The qualitative findings discussed above are, for the most part, robust to alternative specifications of equation (1), as shown in Tables 1B (using CPI inflation), 1C (using lagged unemployment), and 1D (using year-on-year lagged price inflation).

\subsection{Shortcomings}

The evidence reported above, based on OLS estimates of equation (1), has several shortcomings as a measure of the sensitivity of wage inflation to variations in unemployment. Firstly, the specification of (1), while frequently found in textbooks and empirical applications, is generally viewed as being largely adhoc. In Appendix A1 we provide some possible microfoundations for such a specification based on the staggered wage-setting model of Erceg et al. (2000) augmented with partial indexation to (lagged) price inflation and reformulated in terms of unemployment, as in Galí (2011a). The resulting microfounded wage equation takes the form:

$$
\pi_{t}^{w}=\alpha+\gamma \bar{\pi}_{t-1}^{p}-\varphi \widehat{u}_{t}+\psi \widehat{\mu}_{w, t}^{n}
$$

where $\alpha, \gamma, \varphi$, and $\psi$ are functions of structural parameters, and $\widehat{\mu}_{w, t}^{n}$ represents exogenous fluctuations in the natural wage markup. ${ }^{7}$

Under the previous microfounded interpretation, the assumption of orthogonality between the right hand side variables and the disturbance term in (1) that would justify the use of OLS is unlikely to be satisfied in practice. Estimated DSGE models suggest that natural wage markup shocks are far from negligible sources of macro fluctuations. In particular they have significant effects on both price inflation and unemployment. ${ }^{8}$ The latter observation suggests that

\footnotetext{
${ }^{7}$ The natural wage markup is the gap between the average real wage and the marginal rate of substitution that would prevail under flexible wages.

${ }^{8}$ See, e.g. Smets and Wouters (2007) and Galí, smets and Wouters (2012).
} 
reduced form OLS estimates of $\gamma$ and $\varphi$ would likely be inconsistent. Furthermore, changes over time in the volatility of wage markup shocks could be a source of spurious changes in the OLS estimates of those coefficients across subsample periods, giving a misleading impression of a "structural change" in the response of wage inflation to unemployment.

Below we propose and implement an empirical framework that aims at assessing possible changes in the responsiveness of wage inflation to unemployment in a way that overcomes (at least in principle) some of the previous limitations of unconditional reduced form estimates of the wage Phillips curve.

\section{Wage Inflation and Unemployment: Semi-Structural Evidence}

In the present section we describe our empirical approach to identifying the different components of unemployment, wage inflation and price inflation, based on a structural vector autoregression model with time-varying coefficients (TVCSVAR). Our empirical model provides a flexible specification which allows for structural changes in the relation between wage inflation and unemployment, as well as other structural changes that the U.S. economy may have experienced over the sample period considered. ${ }^{9}$ In addition, our framework makes it possible to overcome the potential endogeneity problem discussed above. More generally, our approach allows us to estimate the joint dynamics of wage inflation and unemployment in response to monetary policy interventions, and to uncover any changes over time in those dynamics.

\subsection{Empirical Model}

Let $\mathbf{x}_{t}=\left[\Delta\left(y_{t}-n_{t}\right), \pi_{t}^{w}, \pi_{t}^{p}, u_{t}, i_{t}^{L}\right]$ where $y_{t}$ is (log) GDP, $n_{t}$ denotes (log) hours of all persons in the nonfarm business sector, and $i_{t}^{L}$ is the yield on 10year Government bonds. Price inflation and wage inflation, $\pi_{t}^{w}$ and $\pi_{t}^{p}$, are

\footnotetext{
${ }^{9}$ These may include the change in the cyclical behavior of productivity emphasized in Galí and Gambetti (2009), or the change in monetary policy starting with Paul Volcker's tenure at the Fed (e.g. Clarida, Galí and Gertler (2000))
} 
now defined as quarterly (log) first-differences of wage earnings of production and nonsupervisory workers and of the GDP deflator, respectively, i.e. $\pi_{t}^{w} \equiv$ $w_{t}-w_{t-1}$ and $\pi_{t}^{p} \equiv p_{t}-p_{t-1}$. As above, $u_{t}$ denotes the civilian unemployment rate. We use a long term yield to avoid problems related to the binding zero lower bound at the end of our sample. All data are quarterly. The sample period is 1964Q1-2017Q4.

We assume that $\mathbf{x}_{t}$ admits the TVC-VAR representation

$$
\mathbf{x}_{t}=\mathbf{A}_{0, t}+\mathbf{A}_{1, t} \mathbf{x}_{t-1}+\mathbf{A}_{2, t} \mathbf{x}_{t-2}+\ldots+\mathbf{A}_{p, t} \mathbf{x}_{t-p}+\mathbf{u}_{t}
$$

where $\mathbf{A}_{0, t}$ is a vector of time-varying intercepts, $\mathbf{A}_{i, t}$, for $i=1, \ldots, p$ are matrices of time-varying coefficients, and $\mathbf{u}_{t}$ is a Gaussian white noise vector process with time-varying covariance matrix $\boldsymbol{\Sigma}_{t}$. We assume the reduced form innovations $\mathbf{u}_{t}$ are a (possibly time-varying) linear transformation of the underlying structural shocks $\varepsilon_{t}$ given by

$$
\mathbf{u}_{t} \equiv \mathbf{Q}_{t} \varepsilon_{t}
$$

where $\mathbb{E}\left\{\varepsilon_{t} \varepsilon_{t}^{\prime}\right\}=I$ and $\mathbb{E}\left\{\varepsilon_{t} \varepsilon_{t-k}^{\prime}\right\}=0$ for all $t$ and $k=1,2,3, \ldots$. It follows that $\mathbf{Q}_{t} \mathbf{Q}_{t}^{\prime}=\boldsymbol{\Sigma}_{t}$. As described in the Appendix, our approach assumes all the time-varying coefficients follow random walks with independent innovations.

Estimation is carried out as in Del Negro and Primiceri (2013). ${ }^{10}$ Estimates of (2) can be used to obtain the (local) reduced form moving average (MA) representation:

$$
\mathbf{x}_{t}=\boldsymbol{\mu}_{t}+\mathbf{B}_{t}(L) \mathbf{u}_{t}
$$

Equation (3) can then be used to recover the structural (local) TVC-MA representation:

$$
\mathbf{x}_{t}=\boldsymbol{\mu}_{t}+\mathbf{C}_{t}(L) \varepsilon_{t}
$$

where $\mathbf{C}_{t}(L) \equiv \mathbf{B}_{t}(L) \mathbf{Q}_{t}$, and where $\mathbf{x}_{t}^{i j} \equiv \mathbf{C}_{t}^{i j}(L) \varepsilon_{t}^{j}$ represents the component of the $i$ th variable associated with the $j$ th shock. Determination of $\mathbf{Q}_{t}$ requires a set of assumptions to identify the different shocks (i.e. the different elements of $\varepsilon_{t}$ ) driving fluctuations in $\mathbf{x}_{t}$.

\footnotetext{
${ }^{10}$ We refer the reader to Galí and Gambetti (2016) for details.
} 
We identify technology shocks, following Galí (1999), as the only shocks in vector $\varepsilon_{t}$ to have a long run effect on labor productivity, implemented by imposing $\mathbf{C}_{t}^{1 j}(1)=0$ for all $t$ and $j=2,3,4,5$. In addition to a technology shock, we assume the existence of four additional shocks typically found in estimated DSGE models: (non-monetary) demand shocks, monetary policy shocks, price markup shocks, and wage markup shocks. By construction, those four shocks are restricted to have only transitory effects on labor productivity. We disentangle them through restrictions on the sign of their implied comovements between certain variables over a four-quarter horizon after each shock. ${ }^{11}$ Our sign restrictions are motivated by the predictions of the estimated medium-scale New Keynesian model with unemployment in Galí, Smets and Wouters (2012). ${ }^{12}$ Here are our short-run sign restrictions:

- Demand shocks (to be understood as non-monetary) are assumed to generate a positive comovement among $y_{t}, \pi_{t}^{p}$ and $i_{t}^{L}$.

- Monetary policy shocks imply a positive comovement between $y_{t}$ and $\pi_{t}^{p}$, but a negative comovement between each of those variables and $i_{t}^{L}$.

- Price markup shocks are identified as the only source of fluctuations that generates a positive comovement between $\pi_{t}^{p}$ and the price markup $\mu_{t}^{p} \equiv$ $\left(y_{t}-n_{t}\right)-\left(w_{t}-p_{t}\right)$.

- Wage markup shocks are assumed to be the only structural disturbances that generate a positive comovement between $\pi_{t}^{w}$ and the unemployment rate $u_{t}$, with the latter variable interpreted as a proxy for the wage markup, following Galí (2011a,b).

Table 2 summarizes our identification strategy in a compact way.

\footnotetext{
${ }^{11}$ The use of sign restrictions for identification purposes in structural VARS was pioneered by Uhlig (2005)

${ }^{12}$ That model is itself an extension of those in Smets and Wouters (2007) that introduces an explicit relation between the unemployment rate and the wage markup discussed in Galí (2011b).
} 


\subsection{Conditional Wage Phillips Curves}

The next step in our approach consists of re-estimating the wage Phillips curve (1) using the time series for wage inflation, price inflation and unemployment, purged of the component associated with wage markup shocks obtained using the TVC-SVAR described above. To the extent that the error term in (1) captures fluctuations in wage markup shocks, the estimation of such a conditional wage Phillips curve should overcome any bias resulting from the correlation between the error term and the regressors. ${ }^{13}$

Table 3A reports estimates of coefficients $\gamma$ and $\varphi$ in (1) for different sample periods, using the non-wage markup components of the three variables involved. As in our TVC-SVAR specification, price inflation is measured as the log firstdifference of the GDP deflator. As in our baseline estimates of (1) we annualize both inflation variables before applying OLS. The estimates for the full precrisis period point to a smaller price inflation coefficient (0.32) and a larger (in absolute terms) unemployment coefficient $(-0.55)$ than the "unconditional" estimates of Table 1A. Interestingly, when we now restrict ourselves to the Great Moderation period, we still get a smaller inflation coefficient and larger unemployment coefficient than in the full pre-crisis period, but now the differences in the estimated coefficients are much smaller (and in case of the inflation coefficient, statistically insignificant). When we turn to the crisis and recovery period, we obtain estimates of the inflation and unemployment coefficients that are smaller (in absolute value) than in the pre-crisis period. As in our unconditional estimates of Table 1A for this period, the coefficient on lagged inflation is now insignificant. The estimated coefficient on unemployment is significantly smaller than in the pre-crisis period, though more than twice as large as its unconditional counterpart.

Figures $4 \mathrm{~A}$ and 4B reports time-varying estimates of $\varphi$ and $\gamma$, respectively, based on rolling OLS regressions with a 32-observation window, applied to the

\footnotetext{
${ }^{13}$ Our approach is similar in spirit to that of Barnichon and Mesters (2018a), who estimate a New Keynesian Phillips curve for price inflation using current and lagged monetary policy shocks as instruments.
} 
non-wage markup components of the time series involved. Note that, relative to Figures $3 \mathrm{~A}$ and $3 \mathrm{~B}$, and consistent with the evidence just discussed, the coefficient on unemployment appears to be more stable over time, and to experience a smaller decline in recent years. On the other hand, the conditional rolling estimates of the inflation coefficient display a pattern very similar to their unconditional counterparts, though with slighly lower values in the 1980s.

The previous qualitative findings are largely robust to alternative specifications of conditional wage Phillips curves, as shown in Tables 3B (using lagged unemployment), and 3C (using year-on-year lagged price inflation). An exception to this similarity is given by the estimates of the coefficient on lagged year-on-year inflation in Table 3C, which do not appear to vary significantly across sample periods.

\subsection{Conditional Dynamic Multipliers}

The empirical approach described in the previous subsection should in principle overcome one of the shortcomings of the reduced form evidence, namely, the potential biases in the OLS estimates of equation (1) resulting from the endogeneity of unemployment and inflation with respect to wage markup shocks. Yet, the estimates of conditional wage Phillips curves are still subject to another important caveat, namely, the ad-hoc specification of (1). In the present subsection we uncover possible changes over time in the relation between unemployment and wage inflation without the straitjacket of any assumed functional relation between the two variables. Instead, we focus on the estimated impulse responses generated by our TVC-SVAR and trace the evolution over time of the dynamic wage inflation-unemployment multiplier, defined as a ratio of the cumulative impulse responses of those two variables to a given shock $\varepsilon_{t}^{i}$ at different horizons:

$$
\Phi_{t}^{i}(k) \equiv \frac{\sum_{k=0}^{K} \frac{\partial \pi_{t+k}^{w}}{\partial \varepsilon_{t}^{i}}}{\sum_{k=0}^{K} \frac{\partial u_{t+k}}{\partial \varepsilon_{t}^{i}}}
$$

for $K=0,1,2, \ldots 8$. A similar impulse response-based statistic was originally proposed and implemented in Barnichon and Mesters (2018b) in order to mea- 
sure the sensitivity of price inflation to different slack measures, using a constant coefficient SVAR.

Figure 5A displays the evolution of the above dynamic multiplier conditional on monetary policy shocks. As expected, the multiplier is always negative, suggesting that a monetary shocks tends to move wage inflation and unemployment in opposite directions. We also see that its absolute value declines with the horizon, suggesting a more persistent effect of the shock on unemployment than on wage inflation. More interestingly, however, the (absolute) size of the multiplier appears to decrease over time. This is true at all the horizons considered (up to eight quarters) but particularly so at the shortest horizons. Thus, in the early part of the sample, we see how an expansionary monetary policy shock that drove the unemployment rate down by one percentage point, simultaneously raises (quarterly) wage inflation by about 3 percentage points, implying a multiplier of -3 . That short run multiplier decreases over time in absolute value, to a level close to -1 . That finding is consistent with the evidence in previous sections pointing to a more muted response of wage inflation to fluctuations in unemployment. In contrast with that evidence, however, the present estimates suggest that such a change in responsiveness has been quite gradual, having started well before the financial crisis.

Figure 5B displays analogous evidence for (non-monetary) demand shocks. Many of the qualitative patterns observed in Figure 5A are also present here including the gradual decline in the (absolute) size of the estimated multiplier at all horizons. A different picture, however, emerges in Figure 5C, which displays the dynamic multiplier for price markup shocks, and which does not suggest any major changes over time.

The above evidence rules out a change in the relative importance of different shocks as the main or only source of any reduction in the sensitivity of wage inflation to unemployment fluctuations: a change in that relation appears to have occurred even when one conditions on specific shocks. Unfortunately, our approach cannot shed direct light on the nature of the structural change(s) that may underlie the lower conditional dynamic multipliers. A greater decoupling 
of wage inflation from price inflation, possibly due to a stronger anchoring of inflation expectations associated with the adoption of a price stability-oriented monetary policy, and captured in our estimates of the wage Phillips curve (both conditional and unconditional) would limit the so-called second round effects on wage inflation and dampen the response of the latter variable to any given variation in the unemployment rate, providing a possible explanation to the evidence above. $^{14}$

\section{Conclusions}

We have started the present paper by documenting the changes in the wage Phillips curve, using simple reduced form regressions applied to aggregate U.S. data. In particular, we have provided evidence of a substantial decline in the estimated coefficients on both lagged inflation and unemployment in our wage Phillips curve. We have also provided estimates of conditional wage Phillips curves, based on a structural decomposition of wage, price and unemployment data generated by a VAR with time varying coefficients identified by a combination of long-run and sign restrictions. Our estimated conditional wage Phillips curves show that most qualitative findings from the reduced form evidence are not driven by endogeneity problems or possible changes in the relative importance of shocks, though such factors may have led unconditional reduced form estimates to overstate the some of the actual changes. Finally, we have shown that the reduced sensitivity of wage inflation to unemployment is also reflected in the estimated changes in a dynamic multiplier statistic, based on the estimated time-varying impulse responses to monetary policy and demand shocks.

We draw two main conclusions from our findings. Firstly, we confirm the existence of a growing disconnect between wage inflation and unemployment. Secondly, more research is needed in order to understand the nature of that phenomenon.

\footnotetext{
${ }^{14}$ Blanchard and Galí (2009) point to that mechanism as an explanation of the smaller macroeconomics effects of oil price shocks in the 2000s relative to the 1970s.
} 


\section{REFERENCES}

Barnichon, Régis and Geert Mesters (2018a): "Identifying the Phillips Curve from Shifts in Demand," unpublished manuscript.

Barnichon, Régis and Geert Mesters (2018b): "Direct Estimation of the Inflation-Unemployment Tradeoff," unpublished manuscript.

Blanchard, Olivier and Lawrence Katz (1999): "Wage Dynamics: Reconciling Theory and Evidence," American Economic Review, Vol. 89, No. 2, pp. 69-74

Blanchard, Olivier and Jordi Galí (2009): "The Macroeconomic Effects of Oil Price Shocks: Why are the 2000s so different from the 1970s?" (with O. Blanchard) in J. Galí and M. Gertler (eds.), International Dimensions of Monetary Policy, University of Chicago Press (Chicago, IL), 2009, 373-428

Blanchard, Olivier (2016): "The Phillips Curve: Back to the '60s?" American Economic Review 106(5), 31-34.

Clarida, Richard, Jordi Galí and Mark Gertler (2000): "Monetary Policy Rules and Macroeconomic Stability: Evidence and Some Theory," Quarterly Journal of Economics 115(1), 147-180.

Ciccarelli, M. and C. Osbat (2017), "Low inflation in the euro area: Causes and Consequences", ECB Occasional Paper Series, No 181.

Coibion, Olivier and Yuriy Gorodnichenko (2015), "Is the Phillips curve Alive and Well after All? Inflation Expectations and the Missing Disinflation", American Economic Journal: Macroeconomics, Vol. 7(1), pp. 197-232.

Constancio, Vitor (2017): "Understanding and overcoming low inflation," remarks, Frankfurt, 21-22 September 2017.

Daly, Mary C. and Bart Hobijn (2014): "Downward Nominal Wage Rigidities Bend the Phillips Curve," Journal of Money Credit and Banking 46(2), 51-93.

Del Negro, Marco and Giorgio Primiceri (2013): "Time-Varying Structural Vector Autoregressions and Monetary Policy: A Corrigendum" Federal Reserve Bank of New York Staff Report No. 619.

Erceg, Christopher J., Dale W. Henderson, and Andrew T. Levin (2000): 
"Optimal Monetary Policy with Staggered Wage and Price Contracts," Journal of Monetary Economics vol. 46, no. 2, 281-314.

Galí, Jordi (2011a): "The Return of the Wage Phillips Curve," Journal of the European Economic Association, vol. 9, issue 3, 436-461.

Galí, Jordi (2011b): Unemployment Fluctuations and Stabilization Policies: A New Keynesian Perspective, MIT Press (Cambridge, MA).

Galí, Jordi, Frank Smets and Raf Wouters (2012): "Unemployment in an Estimated New Keynesian Model," NBER Macroeconomics Annual 2011, 329360 .

Galí, Jordi and Luca Gambetti (2009): "On the Sources of the Great Moderation," American Economic Journal: Macroeconomics 1(1), 26-57.

Phillips, A.W. (1958): "The Relation between Unemployment and the Rate of Change of Money Wage Rates in the United Kingdom, 1861-1957," Economica 25, 283-299.

Smets, Frank, and Rafael Wouters (2007): "Shocks and Frictions in US Business Cycles: A Bayesian DSGE Approach," American Economic Review, vol 97 , no. 3, 586-606.

Stock, James H. and Mark W. Watson (2018): "Slack and Cyclically Sensitive Inflation," presented at the ECB Forum on Central Banking.

Uhlig, Harald (2005): "What are the Effects of Monetary Policy on Output? Results from an Agnostic Identification Procedure," Journal of Monetary Economics 52 (2), 381-419 


\section{APPENDIX 2}

\section{A1. Some microfoundations for the wage Phillips curve}

In this appendix we sketch how one may derive our wage Phillips curve from a microfounded model. As shown in Galí (2011), the aggregation of wage decisions by monopolistically competitive unions reoptimizing the nominal wage with a constant probability every period and with partial indexation to a measure of lagged price inflation $\bar{\pi}_{t-1}^{p}$ in case of no reoptimization, implies the following relation between wage inflation and the wage markup gap $\mu_{w, t}-\mu_{w, t}^{n}$, i.e. the gap between the average wage markup, $\mu_{w, t}$, and the natural (or flexible wage) wage markup, $\mu_{w, t}^{n}$

$$
\widetilde{\pi}_{t}^{w}=\beta \mathbb{E}_{t}\left\{\widetilde{\pi}_{t+1}^{w}\right\}-\lambda_{w}\left(\mu_{w, t}-\mu_{w, t}^{n}\right)
$$

where $\widetilde{\pi}_{t}^{w} \equiv \pi_{t}^{w}-\left[\gamma \bar{\pi}_{t-1}^{p}+(1-\gamma) \pi\right]$. Assuming $\mu_{w, t}-\mu_{w, t}^{n} \sim A R(1)$ one can write:

$$
\widetilde{\pi}_{t}^{w}=-\frac{\lambda_{w}}{1-\beta \rho_{w}}\left(\mu_{w, t}-\mu_{w, t}^{n}\right)
$$

In addition, and as shown in Galí (2011), the following relation between the average wage markup and the unemployment rate obtains:

$$
\mu_{w, t}=\vartheta u_{t}
$$

Combining both relations one can derive

$$
\pi_{t}^{w}=(1-\gamma) \pi+\gamma \bar{\pi}_{t-1}^{p}-\frac{\lambda_{w} \vartheta}{1-\beta \rho_{w}} \widehat{u}_{t}+\frac{\lambda_{w}}{1-\beta \rho_{w}} \widehat{\mu}_{w, t}^{n}
$$

where a "hat" represent deviations from an assumed constant mean. Note that the previous specification is consistent with the estimated wage Phillips curve (1), with the error term in the latter capturing exogenous fluctuations in the natural wage markup.

\section{A2. Specification and estimation of the empirical model}


Let $\boldsymbol{\theta}_{t}=\operatorname{vec}\left(\mathbf{A}_{t}^{\prime}\right)$ where $\mathbf{A}_{t}=\left[\mathbf{A}_{0, t}, \mathbf{A}_{1, t} \ldots, \mathbf{A}_{p, t}\right]$ and $\operatorname{vec}(\cdot)$ is the column stacking operator. We assume $\boldsymbol{\theta}_{t}$ evolves over time according to the following equation:

$$
\boldsymbol{\theta}_{t}=\boldsymbol{\theta}_{t-1}+\boldsymbol{\omega}_{t}
$$

where $\boldsymbol{\omega}_{t}$ is Gaussian white noise vector process with covariance matrix $\boldsymbol{\Omega}$.

Time variation of $\boldsymbol{\Sigma}_{t}$ is modeled as follows. Let $\boldsymbol{\Sigma}_{t}=\mathbf{F}_{t} \mathbf{D}_{t} \mathbf{F}_{t}^{\prime}$, where $\mathbf{F}_{t}$ is lower triangular, with ones on the main diagonal, and $\mathbf{D}_{t}$ a diagonal matrix. The vector containing the diagonal elements of $\mathbf{D}_{t}^{1 / 2}$, denoted by $\boldsymbol{\sigma}_{t}$, is assumed to evolve according to the process

$$
\log \boldsymbol{\sigma}_{t}=\log \boldsymbol{\sigma}_{t-1}+\boldsymbol{\zeta}_{t}
$$

Moreover let $\phi_{i, t}$ denote the column vector with the non-zero elements of the $(i+1)$-th row of $\mathbf{F}_{t}^{-1}$. We assume

$$
\phi_{i, t}=\phi_{i, t-1}+\nu_{i, t}
$$

where $\boldsymbol{\zeta}_{t}$ and $\boldsymbol{\nu}_{i, t}$ are Gaussian white noise vector processes with zero mean and (constant) covariance matrices $\boldsymbol{\Xi}$ and $\boldsymbol{\Psi}_{i}$, respectively. We further assume that $\boldsymbol{\nu}_{i, t}$ is independent of $\boldsymbol{\nu}_{j, t}$, for all $j \neq i$, and that $\boldsymbol{\omega}_{t}, \boldsymbol{\varepsilon}_{t}, \boldsymbol{\zeta}_{t}$ and $\boldsymbol{\nu}_{i, t}$ (for all $i$ ) are mutually independent.

\section{Priors Specification}

We make the following assumptions about prior distributions :

$$
\begin{aligned}
\boldsymbol{\theta}_{0} & \sim N\left(\hat{\boldsymbol{\theta}}, 4 \hat{\mathbf{V}}_{\boldsymbol{\theta}}\right) \\
\log \boldsymbol{\sigma}_{0} & \sim N\left(\log \hat{\boldsymbol{\sigma}}_{0}, \mathbf{I}_{n}\right) \\
\boldsymbol{\phi}_{i 0} & \sim N\left(\hat{\boldsymbol{\phi}}_{i}, \hat{\mathbf{V}}_{\boldsymbol{\phi}_{i}}\right) \\
\boldsymbol{\Omega}^{-1} & \sim W\left(\underline{\boldsymbol{\Omega}}^{-1}, \underline{\rho}_{1}\right) \\
\boldsymbol{\Xi}^{-1} & \sim W\left(\underline{\boldsymbol{\Xi}}^{-1}, \underline{\rho}_{2}\right) \\
\boldsymbol{\Psi}_{i}^{-1} & \sim W\left(\underline{\boldsymbol{\Psi}}_{i}^{-1}, \underline{\rho}_{3 i}\right)
\end{aligned}
$$

where $W(\mathbf{S}, d)$ denotes a Wishart distribution with scale matrix $\mathbf{S}$ and degrees of freedom $d$ and $\mathbf{I}_{n}$ is a $n \times n$ identity matrix, with $n$ the number of variables in the VAR. 
We use a time invariant VAR for $\mathbf{x}_{t}$ estimated using the first $\tau=64$ observations to calibrate prior means and variances. $\hat{\boldsymbol{\theta}}$ and $\hat{\mathbf{V}}_{\boldsymbol{\theta}}$ are set equal to the OLS estimates. Let $\hat{\boldsymbol{\Sigma}}$ be the covariance matrix of the residuals $\hat{\mathbf{u}}_{t}$ of the initial time-invariant VAR. We apply the decomposition $\hat{\boldsymbol{\Sigma}}=\hat{\mathbf{F}} \hat{\mathbf{D}} \hat{\mathbf{F}}^{\prime}$ and set $\log \hat{\boldsymbol{\sigma}}_{0}$ equal to the $\log$ of the diagonal elements of $\hat{\mathbf{D}}^{1 / 2} \cdot \hat{\boldsymbol{\phi}}_{i}$ is set equal to the OLS estimates of the coefficients of the regression of $\hat{\mathbf{u}}_{i+1, t}$, the $i+1$-th element of $\hat{\mathbf{u}}_{t}$, on $-\hat{\mathbf{u}}_{1, t}, \ldots,-\hat{\mathbf{u}}_{i, t}$ and $\hat{\mathbf{V}}_{\phi_{i}}$ equal to the estimated variances.

The scale matrices are parametrized as follows: $\underline{\boldsymbol{\Omega}}=\underline{\rho}_{1}\left(\lambda_{1} \hat{\mathbf{V}}_{\boldsymbol{\theta}}\right), \underline{\boldsymbol{\Xi}}=\underline{\rho}_{2}\left(\lambda_{2} \mathbf{I}_{n}\right)$ and $\underline{\boldsymbol{\Psi}}_{i}=\underline{\rho}_{3 i}\left(\lambda_{3} \hat{\mathbf{V}}_{\boldsymbol{\phi}_{i}}\right)$. The degrees of freedom $\underline{\rho}_{1}$ and $\underline{\rho}_{2}$ are set equal to the number of rows $\underline{\boldsymbol{\Omega}}^{-1}$ and $\mathbf{I}_{n}$ plus one respectively while $\underline{\rho}_{3 i}$ is $i+1$ for $i=1, \ldots, n-1$. Finally $\lambda_{1}=0.0002, \lambda_{2}=0.01$ and $\lambda_{3}=0.01$.

\section{Gibbs sampling algorithm}

The Gibbs sampling algorithm is identical to that described in the online appendix of Galí and Gambetti (2015). We use all the data points available from 1964:Q2 to 2017:Q4. We draw 50000 realizations discarding the first 40000 and then taking 1 out of 10 draws, therefore collecting a total of 1000 realizations. 


\begin{tabular}{|c|c|c|c|}
\hline \multicolumn{4}{|c|}{$\begin{array}{c}\text { Table 1A. Empirical Wage Phillips Curves } \\
\text { Earnings, GDP Deflator (Q) }\end{array}$} \\
\hline & $\pi_{t-1}^{p}$ & $u_{t}$ & $R^{2}$ \\
\hline \multicolumn{4}{|l|}{ Pre-Crisis } \\
\hline 1964Q1-2007Q2 & $\begin{array}{l}0.67 \\
(0.04)\end{array}$ & $\begin{array}{c}-0.29 \\
(0.07)\end{array}$ & 0.57 \\
\hline 1986Q1-2007Q2 & $\begin{array}{l}0.17 \\
(0.07)\end{array}$ & $\begin{array}{c}-0.58 \\
(0.07)\end{array}$ & 0.45 \\
\hline$p$ value & 0.003 & 0.016 & \\
\hline \multicolumn{4}{|l|}{ Crisis and Recovery } \\
\hline 2007Q3-2017Q4 & $\begin{array}{l}0.01 \\
(0.12)\end{array}$ & $\begin{array}{c}-0.11 \\
(0.04)\end{array}$ & 0.10 \\
\hline$p$ value 1 & 0.002 & 0.102 & \\
\hline$p$ value 2 & 0.056 & 0.001 & \\
\hline
\end{tabular}




\begin{tabular}{|c|c|c|c|}
\hline \multicolumn{4}{|c|}{$\begin{array}{c}\text { Table 1B. Empirical Wage Phillips Curves } \\
\text { Earnings, CPI (Q) }\end{array}$} \\
\hline & $\pi_{t-1}^{p}$ & $u_{t}$ & $R^{2}$ \\
\hline \multicolumn{4}{|l|}{ Pre-Crisis } \\
\hline 1964Q1-2007Q2 & $\begin{array}{l}0.45 \\
(0.04)\end{array}$ & $\begin{array}{c}-0.16 \\
(0.08)\end{array}$ & 0.42 \\
\hline 1986Q1-2007Q2 & $\begin{array}{l}0.09 \\
(0.04)\end{array}$ & $\begin{array}{c}-0.57 \\
(0.07)\end{array}$ & 0.45 \\
\hline$p$ value & 0.001 & 0.021 & \\
\hline \multicolumn{4}{|l|}{ Crisis and Recovery } \\
\hline 2007Q3-2017Q4 & $\begin{array}{l}0.05 \\
(0.04)\end{array}$ & $\begin{array}{c}-0.11 \\
(0.05)\end{array}$ & 0.14 \\
\hline$p$ value 1 & 0.001 & 0.56 & \\
\hline$p$ value 2 & 0.243 & 0.001 & \\
\hline
\end{tabular}




\begin{tabular}{|c|c|c|c|}
\hline \multicolumn{4}{|c|}{$\begin{array}{c}\text { Table 1C. Empirical Wage Phillips Curves } \\
\text { Earnings, GDP Deflator (Q), Lagged Unemployment }\end{array}$} \\
\hline & $\pi_{t-1}^{p}$ & $u_{t-1}$ & $R^{2}$ \\
\hline \multicolumn{4}{|l|}{ Pre-Crisis } \\
\hline 1964Q1-2007Q2 & $\begin{array}{l}0.65 \\
(0.04)\end{array}$ & $\begin{array}{c}-0.22 \\
(0.07)\end{array}$ & 0.55 \\
\hline 1986Q1-2007Q2 & $\begin{array}{l}0.16 \\
(0.07)\end{array}$ & $\begin{array}{c}-0.56 \\
(0.07)\end{array}$ & 0.43 \\
\hline$p$ value & 0.014 & 0.367 & \\
\hline \multicolumn{4}{|l|}{ Crisis and Recovery } \\
\hline 2007Q3-2017Q4 & $\begin{array}{l}0.01 \\
(0.11)\end{array}$ & $\begin{array}{c}-0.15 \\
(0.05)\end{array}$ & 0.18 \\
\hline$p$ value 1 & 0.002 & 0.34 & \\
\hline$p$ value 2 & 0.020 & 0.001 & \\
\hline
\end{tabular}




\begin{tabular}{r|ccc}
\hline \hline \multicolumn{4}{c}{ Table 1D. Empirical Wage Phillips Curves } \\
Earnings, GDP Deflator (YOY)
\end{tabular}




\begin{tabular}{l|ccccccc}
\hline \hline \multicolumn{7}{c}{ TABLE 2. Identification } \\
\hline & $y_{t}-n_{t}$ & $\pi_{t}^{w}$ & $u_{t}$ & $\pi_{t}^{p}$ & $\mu_{t}^{p}$ & $i_{t}^{L}$ \\
\hline Technology & & & & & & \\
Demand & $0_{\infty}$ & + & - & + & - & + \\
Monetary Policy & $0_{\infty}$ & + & - & + & - & - \\
Price Markup & $0_{\infty}$ & $+/-$ & $-/+$ & + & + & \\
Wage Markup & $0_{\infty}$ & + & + & $+/-$ & $-/+$ & \\
\hline \hline
\end{tabular}




\begin{tabular}{|c|c|c|c|}
\hline \multicolumn{4}{|c|}{$\begin{array}{c}\text { Table 3A. Conditional Wage Phillips Curves } \\
\text { Earnings, GDP Deflator }(\mathrm{Q})\end{array}$} \\
\hline & $\pi_{t-1}^{p}$ & $u_{t}$ & $R^{2}$ \\
\hline \multicolumn{4}{|l|}{ Pre-Crisis } \\
\hline 1964Q1-2007Q2 & $\begin{array}{l}0.32 \\
(0.04)\end{array}$ & $\begin{array}{c}-0.55 \\
(0.07)\end{array}$ & 0.39 \\
\hline 1986Q1-2007Q2 & $\begin{array}{l}0.21 \\
(0.05)\end{array}$ & $\begin{array}{c}-0.74 \\
(0.06)\end{array}$ & 0.64 \\
\hline$p$ value & 0.226 & 0.019 & \\
\hline \multicolumn{4}{|l|}{ Crisis and Recovery } \\
\hline 2007Q3-2017Q4 & $\begin{array}{l}0.07 \\
(0.09)\end{array}$ & $\begin{array}{c}-0.29 \\
(0.05)\end{array}$ & 0.10 \\
\hline$p$ value 1 & 0.24 & 0.04 & \\
\hline$p$ value 2 & 0.36 & 0.001 & \\
\hline
\end{tabular}




\begin{tabular}{|c|c|c|c|}
\hline \multicolumn{4}{|c|}{$\begin{array}{l}\text { Table 3B. Conditional Wage Phillips Curves } \\
\text { Earnings, GDP Deflator (Q), Lagged Unemployment }\end{array}$} \\
\hline & $\pi_{t-1}^{p}$ & $u_{t-1}$ & $R^{2}$ \\
\hline \multicolumn{4}{|l|}{ Pre-Crisis } \\
\hline 1964Q1-2007Q2 & $\begin{array}{l}0.31 \\
(0.05)\end{array}$ & $\begin{array}{c}-0.40 \\
(0.00)\end{array}$ & 0.31 \\
\hline 1986Q1-2007Q2 & $\begin{array}{l}0.20 \\
(0.06)\end{array}$ & $\begin{array}{c}-0.70 \\
(0.07)\end{array}$ & 0.44 \\
\hline$p$ value & 0.199 & 0.009 & \\
\hline \multicolumn{4}{|l|}{ Crisis and Recovery } \\
\hline 2007Q3-2017Q4 & $\begin{array}{l}0.07 \\
(0.08)\end{array}$ & $\begin{array}{c}-0.32 \\
(0.05)\end{array}$ & 0.56 \\
\hline$p$ value 1 & 0.28 & 0.46 & \\
\hline$p$ value 2 & 0.34 & 0.001 & \\
\hline
\end{tabular}




\begin{tabular}{r|ccc}
\hline \hline \multicolumn{4}{c}{ Table 3C. Conditional Wage Phillips Curves } \\
Earnings, GDP Deflator (YOY)
\end{tabular}




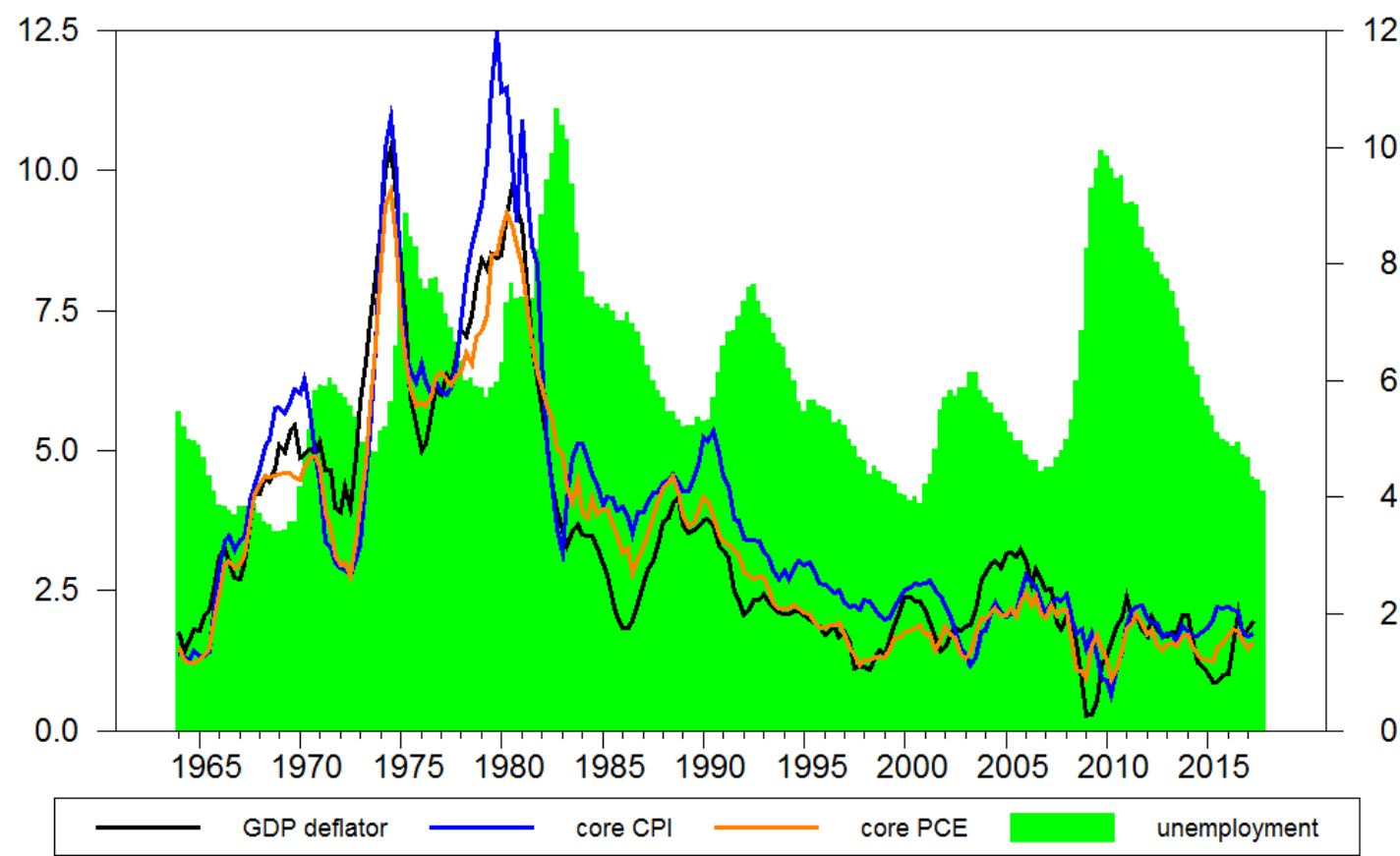

Figure 1. Unemployment and Price Inflation 


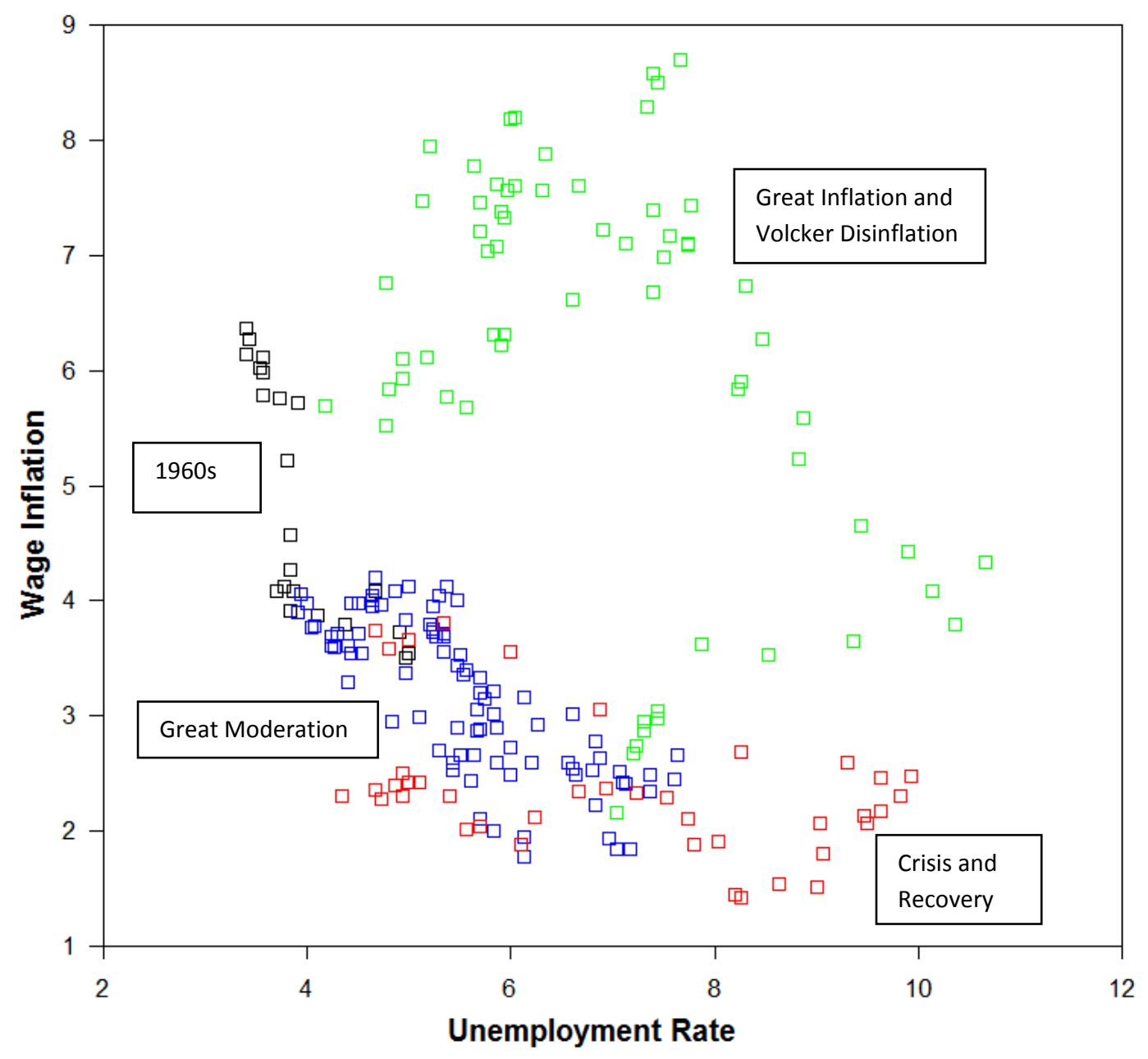

Figure 2. The U.S. Wage Phillips curve 


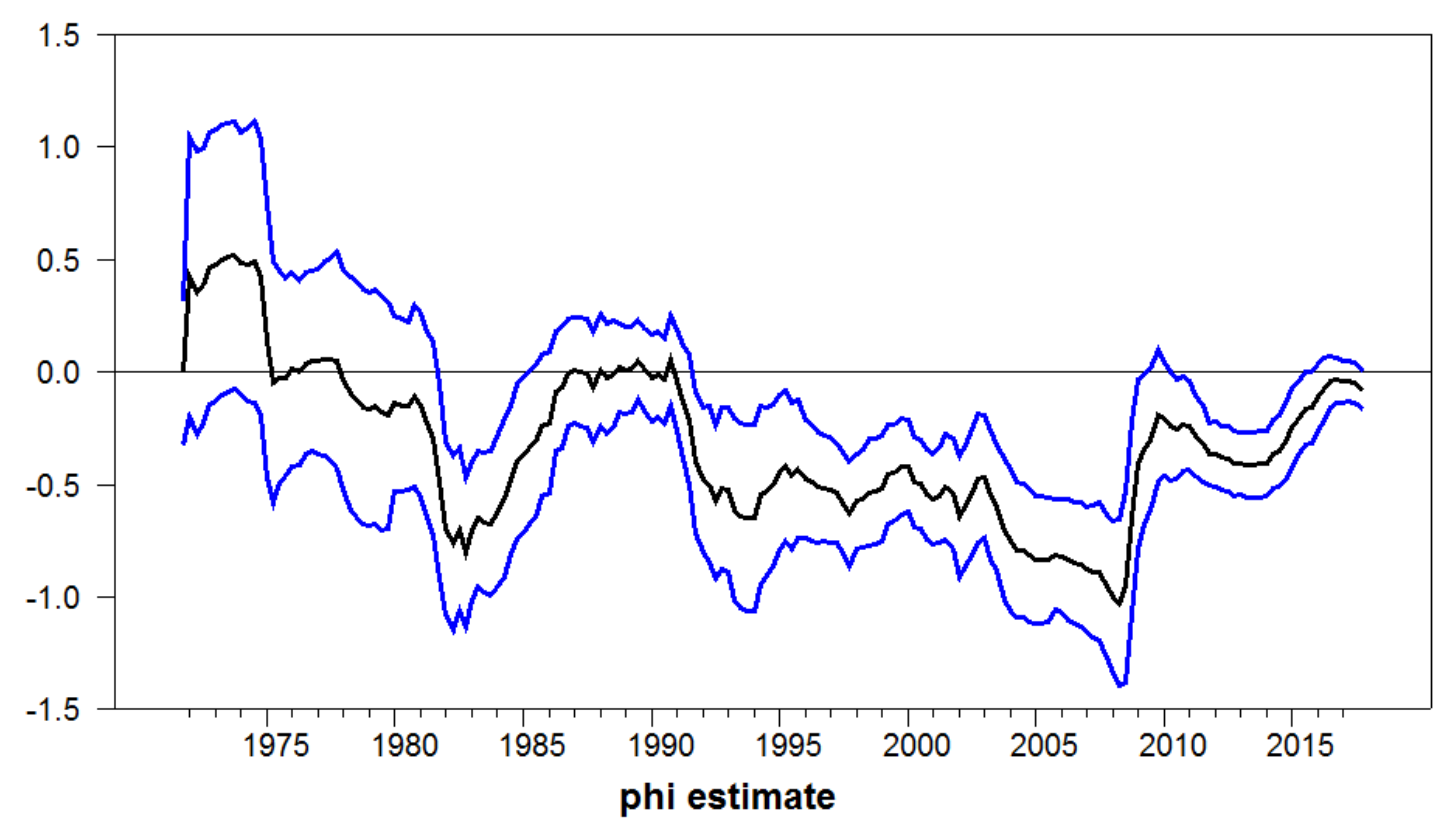

Figure 3A. Unemployment Coefficient (unconditional estimate)

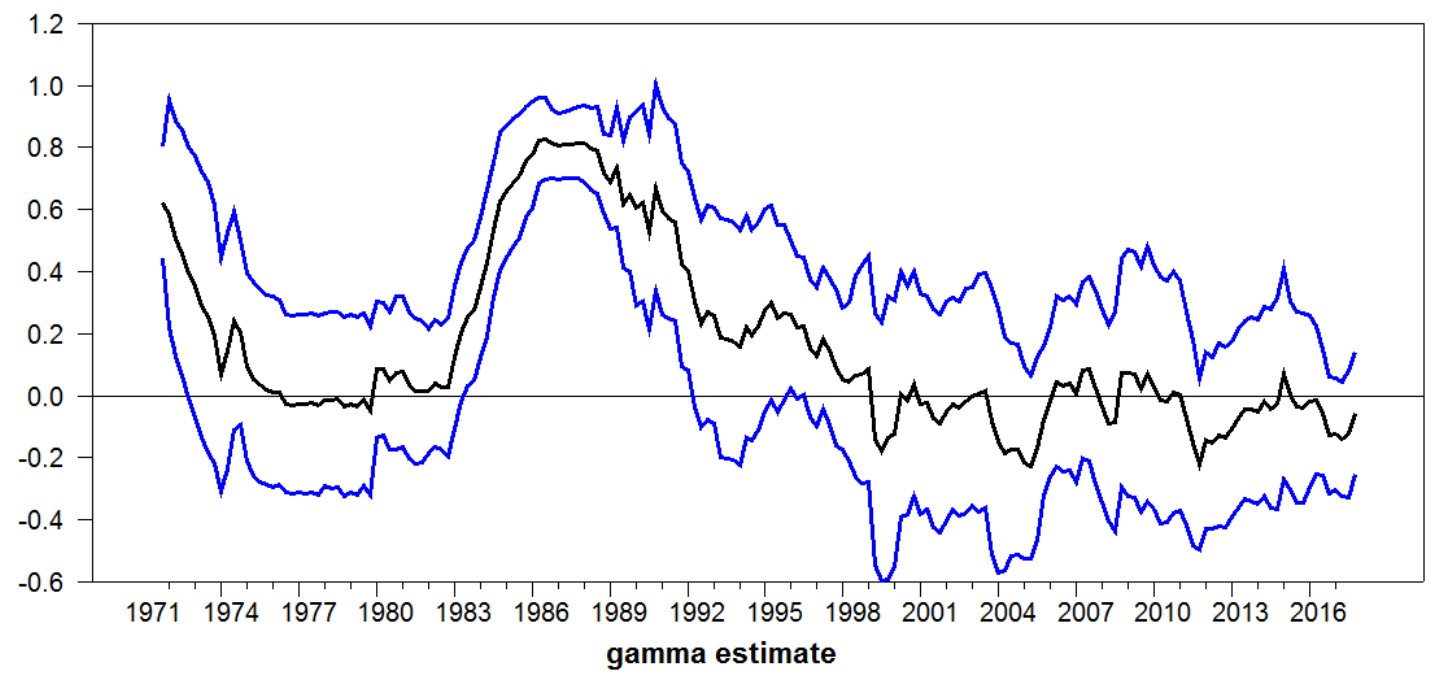

Figure 3B. Inflation Coefficient (unconditional estimate) 


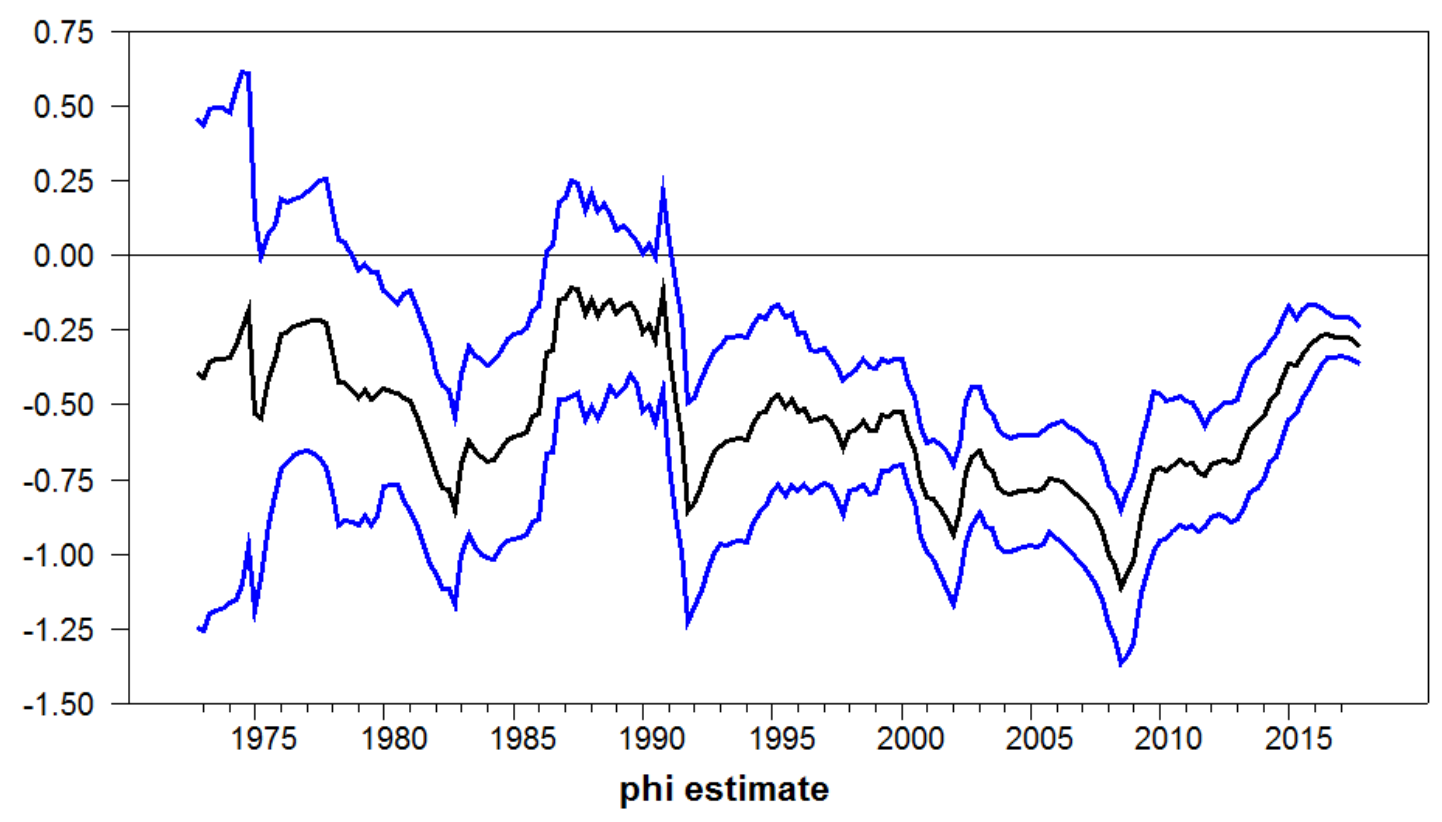

Figure 4A. Unemployment Coefficient (conditional estimate)

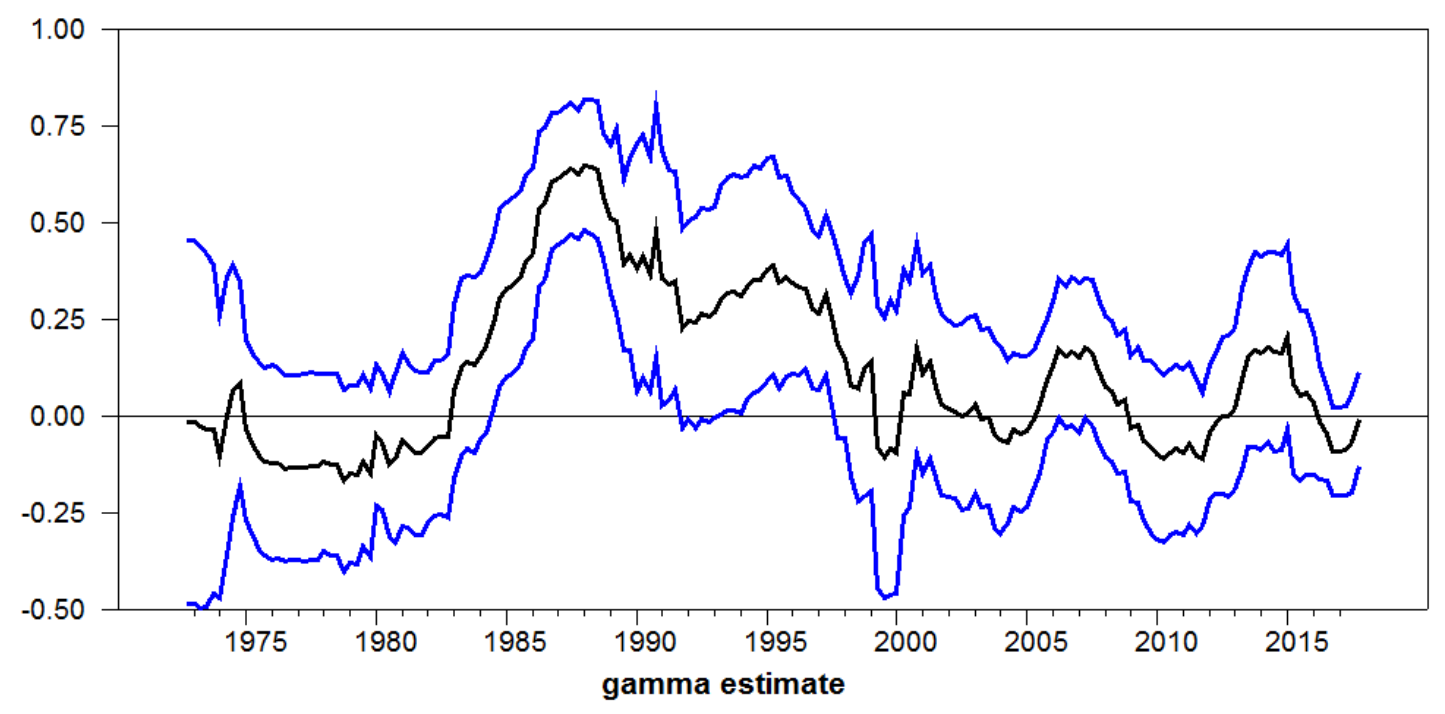

Figure 4B. Inflation Coefficient (conditional estimate) 


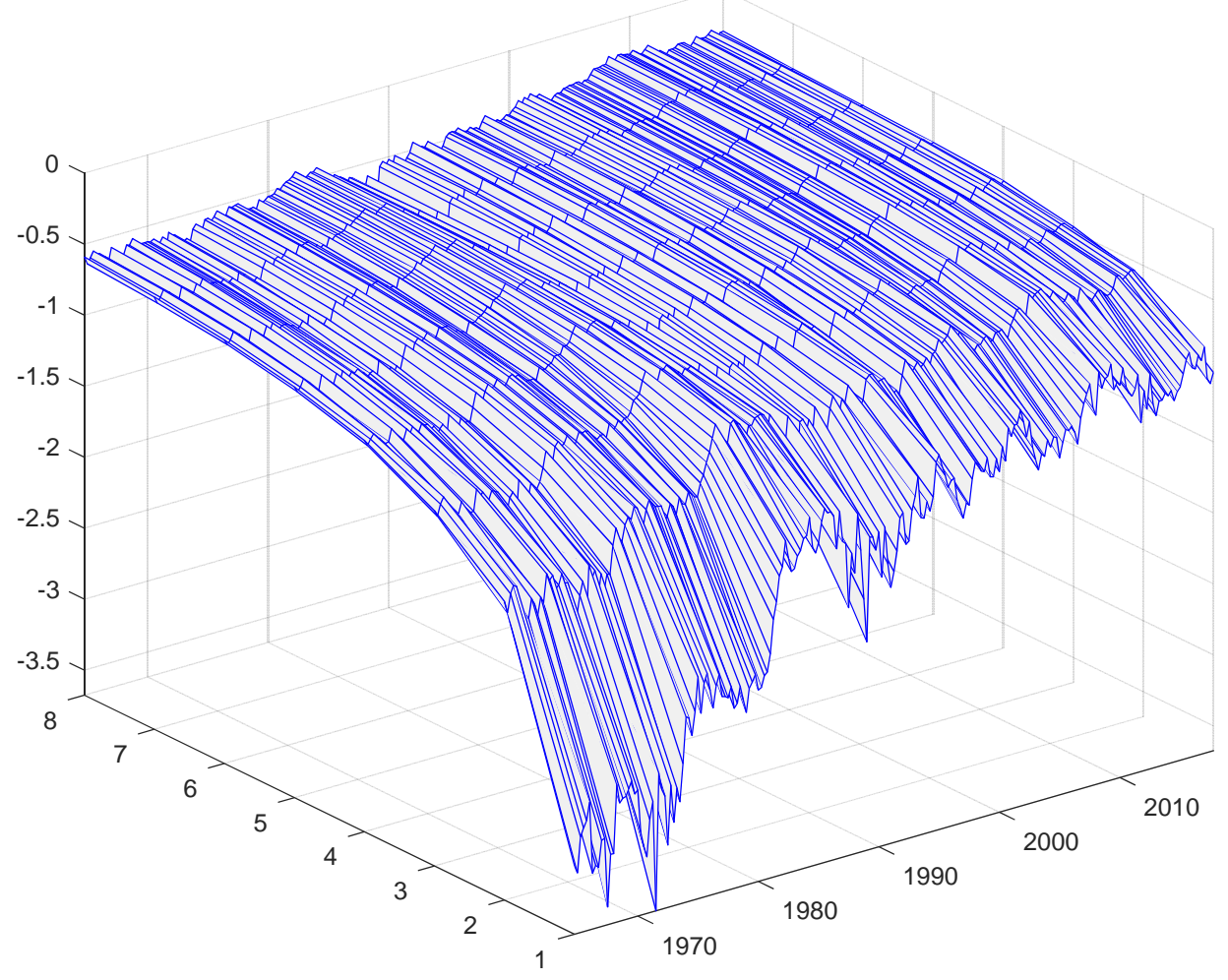

Figure 5A. Dynamic Multiplier: Monetary Policy Shocks 


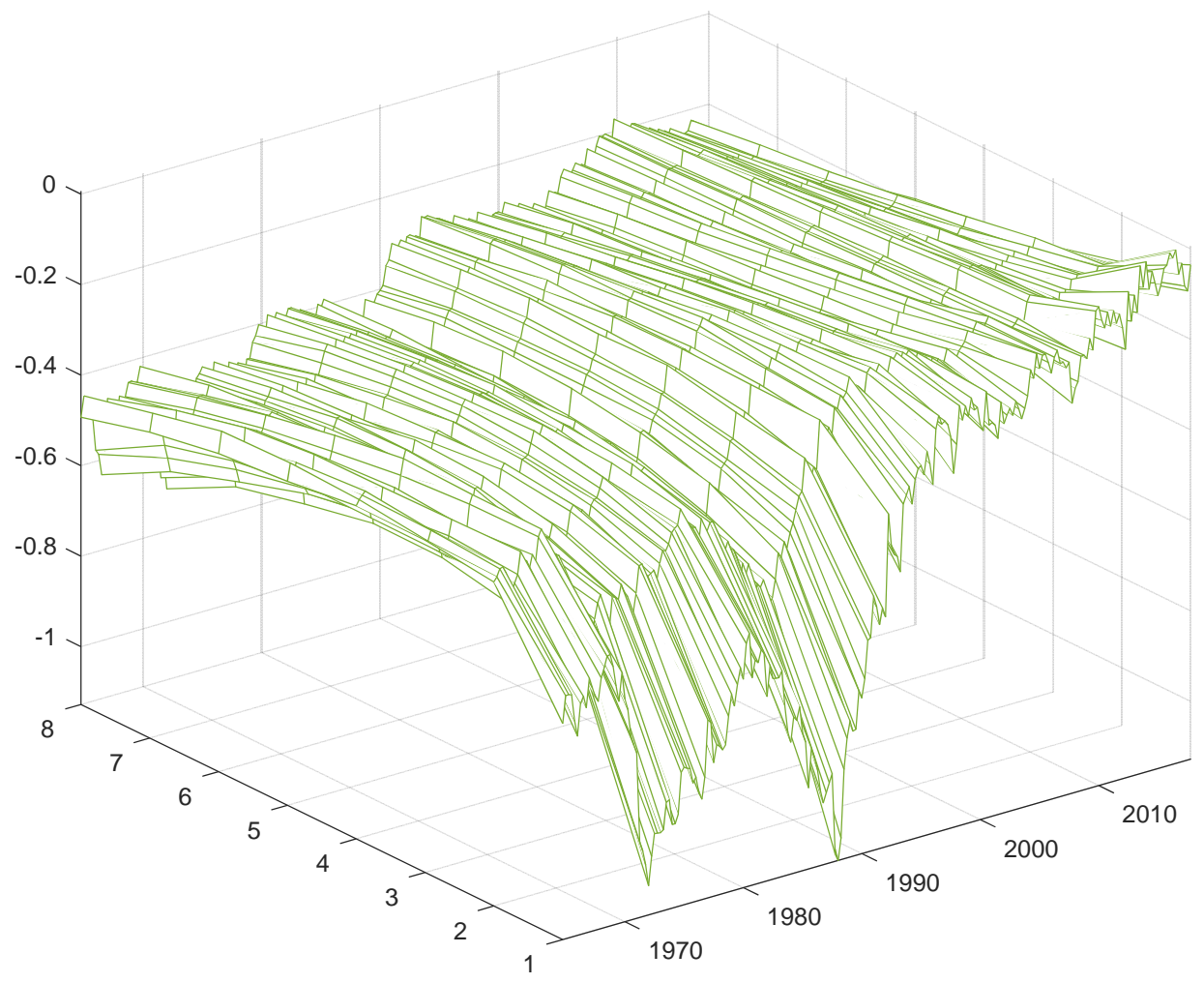

Figure 5B. Dynamic Multiplier: Demand Shocks 


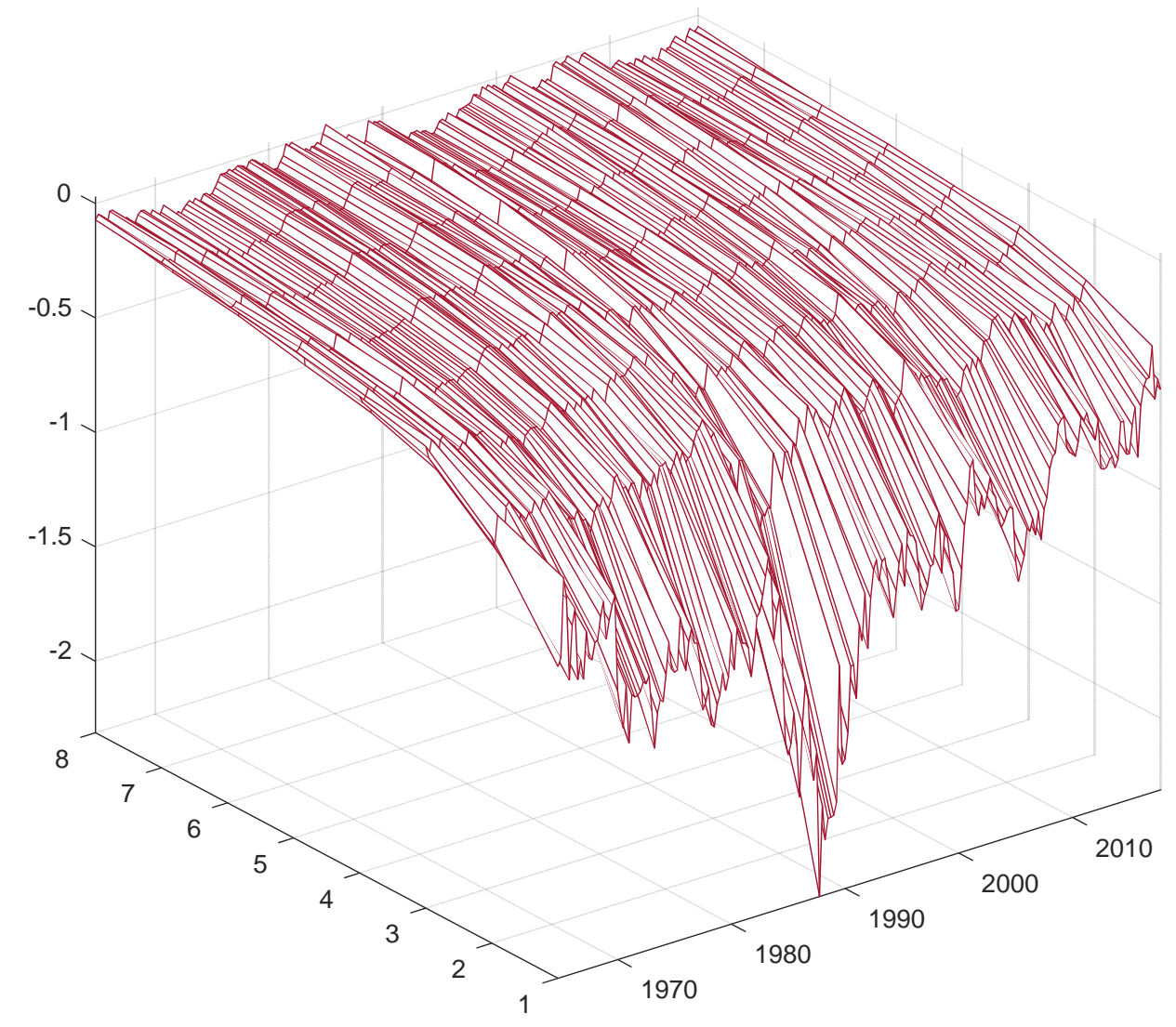

Figure 5C. Dynamic Multiplier: Price Markup shocks 